\title{
ETHICS OF THE CONDUCT OF STATE SERVANTS AS A QUALITATIVE COMPONENT OF THE CONTENT OF PUBLIC ADMINISTRATION
}

\author{
Bilokur Ye. I., Danylenko Yu. S.
}

\section{INTRODUCTION}

Implementation of administrative reform and adaptation of the state service institute to European standards necessitates a complete «reset» of all state institutions and relations with the participation of the state, which requires a radical revision of approaches to the formation of normative support for public authorities in general and state servants in particular. Despite significant changes in the legal framework in almost all public and legal relations, the positive assessments of experts on the quality of domestic regulations adopted over the past ten years, their compliance with the basic standards of the European Union, the main problem remains in ensuring their implementation without distortions due to the corruption component.

It appears that this situation is connected with the fact that reforms are carried out solely in terms of their «technicality» without taking into account the subjective factor - reducing the general and professional culture of decision-makers - especially state servants at all levels. Forming the personality of a state servant as a highly professional, disciplined, tolerant, but at the same time a person of principle is a complex and long process. However, only such a state servant is able to change the situation in Ukraine in favour of not only declarative renewal and further reform, but also to ensure real progress in building a qualitatively new state - a state that is an equal member of the European community. The first step in achieving this goal should be a clear formulation of ethical requirements for the activities of state servants and constant monitoring of their compliance in practice, which together will improve the moral and ethical climate in the state service.

Thus, today the problem of determining the ethics of state servant conduct, which focuses on the values of a democratic legal and social state, service to the people of Ukraine, professional competence, ability to implement the functions of public authority effectively, within the law and official powers and promote a new positive image of the state and its authorities.

The relevance of the scientific research direction is also enhanced by the fact that the consolidation and regulation of rules of ethical conduct of state 
servants is intended to: firstly, facilitate the prevention of the commission of corruption or corruption-related offenses by the state servants; secondly, to ensure an increase in the level of official discipline during service in public authorities; thirdly, to increase the personal responsibility of state servants for the performance of their official duties.

\section{Substantive and conceptual characteristics of the ethics of conduct of state servants as a qualitative component of the content of public administration}

The definition «administration» is known to be used in such meanings as: 1) management; 2) regulation; 3) the activity of the public administration on realization of the duties assigned to it and satisfaction of the general public interests; 4) formal-bureaucratic management, which is implemented by issuing orders and / or directions. The peculiarity of administration is that it is realized in specific relations, a sign of which is the inequality of the parties. And such inequality has not only an organizational, but also a legal basis - in this case the priority of the subject of power operates. This means that one party - the subject of authoritative powers - to solve a range of problems is endowed with powers that the other party does not have, or they are insufficient to solve the problems on their own. In this sense, the relations arising during conducting public administration are of an administrative nature: the decision of a public authority does not depend on the consent of the other party, as this body and its officials act on the basis and within the law. At the same time, subordination in such legal relations can be achieved through the use of different methods and based on different principles: it can be voluntary if the interests of the governing and subordinate parties coincide, or coercive when they differ significantly. Without moral principles that guide the interaction of both parties and ensure voluntary subordination, it is impossible to ensure effective activity ${ }^{1}$.

The outlined features are directly related to the official activities of state servants, which determines the specific role of professional ethics in the state service, which consists in that compliance with the rules of ethical conduct is an integral part of the content of public administration, starting with the theoretical justification of goals' and objectives' humanity, organizational and legal support of their practical implementation, scientific explanation of the decision on effective ways of implementation, adequate resource

${ }^{1}$ Рудакевич M.I. Професійна етика державних службовців: теорія і практика формування в умовах демократизації державного управління: монографія. Тернопіль: Видво АСТОН, 2007. C. 95. 
provision, organization of joint activities to perform functions, its control up to the evaluation of the results and consequences from a moral point of view. It seems that this means that the ethics of conduct of state servants in its content is part of other legal regulators: regulations, principles of state service, tools of personnel technology. The ethics of state servants' conduct as a regulator of legal relations is manifested in the fact that it ensures the implementation of humanistic principles in management, providing a more effective approval of the «human-centric» model of state building.

In lexical terms, «ethics» comes from the word «ethos» and is translates as life, customs, character. Ethics by its nature is a philosophical knowledge of morality and moralities, their essence and place in human life. In addition, ethics is seen as certain moral principles and values that operate within a particular profession or activity, a special professional type of which is the ethics of conduct of state servants ${ }^{2}$.

The meaning of the term «ethics of a state servant» is not defined at the legislative level, and in the scientific literature there are different approaches to its understanding, including the following: 1) it is based on awareness of professional purpose and values of state service in the minds of state servants, guide and regulate their relations and activities in the field of state service ${ }^{3} ; 2$ ) a set of agreed moral norms and rules of individual and joint action that meet constitutional values and are optimal in terms of the purpose of professional activity, as well as ways to achieve $i t^{4}$; 3) a set of ethical principles and norms that are expressed in the general form of moral requirements for the moral essence of a state servant, the purpose of his activities, the nature of his relationship with the state ${ }^{5}$. Thus, in modern scientific works, the ethics of a state servant is often defined as a set of moral rules of conduct, the essential characteristics of which contain one and / or two components of the ethical system in the state service, including values and norms. Moreover, when defining the concept under study, the personal component of the ethical conduct of state servants is overlooked and the limits of the spread of such rules are not determined.

\footnotetext{
${ }^{2}$ Публічна служба. Зарубіжний досвід та пропозиції для України / за заг. ред. Тимощука В.П., Школика А.М. Київ: Конус Ю, 2007. С. 84.

${ }^{3}$ Василевська Т.Е. Особистісні виміри професійної етики державного службовця: дис. ... докт. наук з держ. упр-ня.. Киїів, 2009. С. 82.

${ }^{4}$ Рудакевич М.I. Професійна етика державних службовців: теорія і практика формування в умовах демократизації державного управління: монографія. Тернопіль: Видво АСТОН, 2007. C. 97.

${ }_{5}^{5}$ Ethics in the public service: Current issues and practice. Paris: OECD, 1996. p. 14 (Series «Public Management Occasional Papers», no. 14).
} 
The above-mentioned determines the possibility of defining the ethics of state servant conduct as a legally defined system of ethical norms and principles, procedures, rules and relationships not only in state service relations, but also outside them, based on the values of state service and awareness of state servants. Consequently, the peculiarity of the ethics of conduct of state servants is that it goes beyond purely official activities.

The specifics of the ethics of conduct of state servants in the categorical definition has the following features:

features of categories of state servants' ethics are correlated with general ethical categories as individual and general;

categories of state servants' ethics reflect professional activity and social phenomena through the prism of humanistic attitude to the person and the citizen as to the highest value of a society ${ }^{6}$;

regulating professional relations, the ethics of conduct of state servants reproduces their coordination and subordination nature;

the studied rules of ethical conduct are enshrined not only in the norms, principles of state service, codes of ethics, but they also have a by-law basis, etc.

It appears that the ethics of conduct of state servants in its content combines such basic components as: a) motivational (attitude of state servants to the functioning of the state service in general, and the practical implementation of tasks and functions of the state in particular; b) cognitive (theoretical knowledge in the field of professional ethics, its legal consolidation); c) regulatory (direction of activity on realization of principles of state service, realization of the human and civil rights and freedoms); d) emotional and volitional (the presence of certain personal qualities: the ability to work in a team, initiative, discipline). These components are a theoretical (a set of lifelong ethical knowledge and moral values) and practical (attitudes to the proper conduct and application of acquired knowledge in professional activities) component of the ethics of state servants.

The peculiarity of the ethics of state servants' conduct is that it goes beyond purely official activities. Therefore, it seems possible to distinguish two groups of rules of ethical conduct depending on the limits of their distribution: 1) rules that apply to the official activities of state servants; 2) rules that apply to his conduct outside of official activities and regulate privacy.

The first group should include rules of ethical conduct applicable to the working hours of state servants and requirements to eliminate conflicts of

${ }^{6}$ Рудакевич M.І. Професійна етика державних службовців: теорія і практика формування в умовах демократизації державного управління: монографія. Тернопіль: Видво АСТОН, 2007. C. 98. 
interest and prevent corruption. These rules are a set of instructions that determine the meaningful moral content of the professional activities of state servants (as an example, service to the people of Ukraine; professionalism and competence, legality, tolerance, impartiality, professional etiquette). Requirements for the elimination of conflicts of interest and prevention of corruption compose a system that covers the requirements of impartiality, in particular for the notification of the existence of a conflict of interest, both real and potential, its prevention or settlement; the obligation to self-recusal in resolving the issue of holding a position, which provides for the existence of direct official relations with relatives; political neutrality; inadmissibility of receiving any illegal benefit or gift; the obligation to report the violation of the requirements of the state service legislation by another servant, whether they contain signs of corruption.

The second group of ethical requirements is not directly related to the performance of official activities and is a system of requirements for a state servant outside his professional activity, but indicate the general moral level of a state servant (for example, inadmissibility of disrespect for state symbols, territorial integrity and state sovereignty; unacceptable conduct that discredits the public body in which the state servant holds office).

For violation of the rules of ethical conduct by state servants, the following types of legal consequences are applied to them: 1) bringing to legal responsibility: a) criminal - for violating the restrictions on obtaining illegal benefits (Article 368 «Acceptance of an offer, promise or illegal benefit by an official» Criminal Code of Ukraine $^{7}$ ); b) administrative - for violating the anti-corruption restrictions and obligations, which are included in the rules of ethical conduct (Articles 172-4 «Violation of restrictions on part-time job and concurrent service», 172-5 «Violation of statutory restrictions on obtaining gifts», 172-8 «Illegal use of information that became known to a person in connection with the performance of official or statutory powers», 172-9-1 «Violation of the prohibition of betting on sports related to the manipulation of official sports competitions» Code of Ukraine on Administrative Offenses $^{8}$ ); c) disciplinary - is the most common legal consequence of violating the rules of ethical conduct of state servants. In accordance with Art. 65-66 of the Law of Ukraine «On State Service»

\footnotetext{
${ }^{7}$ Кримінальний кодекс України: Закон України від 5.04.2001 р. № 2341-III. Дата оновлення: 05.06.2020 p. URL: https://zakon.rada.gov.ua/laws/show/2341-14\#Tехt (дата звернення: 1.06 .2020 р.).

${ }^{8}$ Кодекс про адміністративні правопорушення України від 07.12.1984 р. Дата оновлення: 19.01.2020 p. URL: https://zakon.rada.gov.ua/laws/show/80731-10 (дата звернення: 1.06.2020 p.).
} 
violation of the rules of ethical conduct is a disciplinary offense, which provides for disciplinary proceedings in the form of a warning of incomplete official compliance 9 ; 2) the occurrence of organizational and procedural consequences - taking into account the compliance with the rules of ethical conduct of state servants when evaluating the results of their official activities, which affects the final assessment and the decision on awarding, career planning; in the form of the use of such a procedural tool as recusal or self-recusal (as an example, in the case of unethical conduct of a member of the police commission, which may cast doubt on his impartiality).

It should be emphasized that the content of rules of ethical conduct and, accordingly, the specification of possible cases of their violation are not legally formalized, which makes it necessary to apply the discretion of the head of a state servant, which leads to subjective interpretation of such evaluative concepts as «ethical rules of conduct», «generally accepted decency requirements», «proper appearance», etc. And even if an act is found to be a violation of ethical requirements, it can be classified as several types of disciplinary offenses. For example, unethical conduct of a state servant during off-duty hours, accompanied by obscene language, references to the importance of his position, threats and abasement of human dignity, falls under the characteristics of three separate types of disciplinary offenses under Part 2 of Article 65 of the Law «On State Service»): committing an act that harms the authority of the state service; violation of the rules of ethical conduct of state servants; violation of the Oath of a state servant ${ }^{10}$.

\section{The current state of legislative regulation of the ethics of conduct of state servants}

The emphasis on regulating the rules of ethical conduct of state servants and translating them into the legal plane is not traditional for European countries, but in Ukraine it is appropriate because for a long time there was the decline of public morality, the usual perception of officials as corrupt, that contributed to that state servants acquired an immunity to the public condemnation. Therefore, the establishment of clear ethical rules of conduct for state servants while determining the degree of responsibility contributes to the formation of awareness of their mission and ensures the effectiveness, efficiency and quality of professional duties.

\footnotetext{
${ }^{9}$ Про державну службу: Закон України від 10.12.2015 р. Дата оновлення 01.01.2020 p. URL: http://zakon2.rada.gov.ua/laws/show/889-19 (дата звернення: 01.06.2020 p.).

10 Адміністративне право України. Повний курс: підручник. Херсон: ОЛДІ-ПЛЮС, 2019. C. 336 .
} 
Furthermore, the consolidation of the rules of ethical conduct of state servants at the regulatory level is determined by such factors as: 1) the state service must comply not only with legal but also ethical norms; 2) rules of ethical conduct play a preventive anti-corruption role, as the very fact of their observance protects a state servant from committing corruption or corruption-related offenses. Therefore, it is quite fair to refer the rules of ethical conduct to legal means of preventing corruption by international and national legal acts (in particular, Articles 8, 11 of the UN Convention against Corruption ${ }^{11}$ and Section 6 of the Law of Ukraine «On Prevention of Corruption» ${ }^{12}$ ); 3) the existence of organizational and professional components of official activity, which cause an increased moral and ethical burden on state servants, requiring special attention to the rules of their ethical conduct. Among such components are the following: «aquarium effect» (is the constant attention of society to government officials, which is often manifested in the observation of their conduct in the off-hours, accompanied by higher criteria for assessing their morality and leads to stable psychological stress); non-specialized appeals and excessive expectations from individuals; the possibility of a contradiction between autonomous morality and public duty; inconsistency of the social mission of the public service with the level of its prestige, etc ${ }^{13}$.

First of all, when researching the legal basis of the ethics of conduct of state servants, it is necessary to clarify the value and normative principles of the Ukrainian state, which are defined by the Constitution of Ukraine. According to Art. 1 «Ukraine is a sovereign and independent, democratic, social, legal state», i.e. this norm proclaims the democracy as a social value. According to Art. 3 the highest value of the Ukrainian state is the person who is the source of power (Articles 3, 5). Life and health, honour and dignity, rights and freedoms, free and comprehensive development are enshrined as institutional values of the state and the norms of their relations. As ethical values it can also be considered freedom, equality, social justice (Articles 23-24), the principle of legality (Article 19), and so on. These norms seem to characterize the basis of the moral and political structure of a democratic state, the social and natural environment of human life, and are designed to provide equal conditions for free and comprehensive

${ }^{11}$ Конвенція Організації Об'єднаних Націй проти корупції від 31.10 .2003 p. URL: https://zakon.rada.gov.ua/laws/show/995_c16\#Техt (дата звернення: 01.06.2020р.).

12 Про запобігання корупції: Закон України від 14.10.2014 р. Дата оновлення 30.03.2020 p. URL: http://zakon2.rada.gov.ua/laws/show/1700-18 (дата звернення: 02.06.2020 p.).

13 Адміністративне право України. Повний курс: підручник. Херсон: ОЛДІ-ПЛЮС, 2019. C. 333 . 
development of citizens, self-realization, as well as the ability to manage public affairs and free access to state service (Articles 5, 11, 17, 21, 23, 36, $38,40,55,65)$. These constitutional values are the criteria for assessing the degree of humanitarianization of the state in general, and the activities of state servants in particular ${ }^{14}$.

The Law of Ukraine "On State Service»" ${ }^{15}$ defines the basic moral values in the activities of a state servant. Ethical norms reflect the practical expediency of those forms of professional relations that have acquired moral certainty and stability. They are divided into norms-prohibitions, norms-frameworks, norms-samples. Prospects for the transition to legal norms are precisely the norms-prohibitions and norms-frameworks. In particular, ethical requirements are enshrined in the rules that define the responsibilities of state servants, restrictions on entry and service in the state service, the grounds for disciplinary action, so we can say that the ethics of state servants is part of these elements. At the same time, the disadvantage of enshrining the rules of ethical conduct in this Law is that it only mentions the need to comply with ethical norms, but without defining its understanding from a legal point of view.

The Law of Ukraine «On Prevention of Corruption» (Section 6) establishes generalized rules of conduct for state servants, which at the same time serve as a legal basis for codes and standards of professional ethics for all public servants (police, judges, prosecutors, etc.) ${ }^{16}$. According to this Law, state servants must adhere to the following rules of ethical conduct in their activities:

1) observance of the priority of interests - a state servant in his activity must avoid situations in which the private interest will prevail over the state, i.e. all actions are directed solely for the public good;

2) political neutrality - prevention of the influence of political interests on the actions and decisions of a state servant, refusal to demonstrate political views and sympathies and beliefs, prohibition of the use of symbols of political parties in the performance of their official duties;

${ }_{14}$ Конституція України. Із змінами, внесеними Законом України від 08.12.2004 p. № 2222IV. Дата оновлення 01.01.2020 p. URL: http://zakon2.rada.gov.ua /laws/show/254\%D0\%BA/96$\% \mathrm{D} 0 \% \mathrm{~B} 2 \% \mathrm{D} 1 \% 80$ (дата звернення: 01.06.2020 р.).

15 Про державну службу: Закон України від 10.12.2015 р. Дата оновлення 01.01.2020 p. URL: http://zakon2.rada.gov.ua/laws/show/889-19 (дата звернення: 01.06.2020 p.).

16 Даниленко Ю.С., Назарчук А.В. Щодо питання змістовної характеристики правил етичної поведінки державних службовців. Верховенство права у прочесі державотворення та захисту прав людини в Україні: матеріали міжнародної науково-практичної конференції (м. Одеса, Україна, 7-8 лютого 2020 р.). Одеса: ГО «Причорноморська фундація права», 2020. C. $112-114$. 
3) impartiality - official activity should not depend on private interests and personal views and beliefs of state servants;

4) competence and efficiency - the ability of a state servant within the powers defined by the position to apply special knowledge, skills and abilities, to identify appropriate moral and business qualities for the proper performance of tasks and responsibilities, training, professional and personal development ${ }^{17}$;

5) non-disclosure of information - information of a confidential nature, which is held by a state servant in connection with the performance of official duties, is kept secret and is not disclosed, except as provided by current law;

6) refraining from carrying out illegal decisions and instructions - this rule of ethical conduct does not reach the level of the fundamental ethical basis of the state service, acting as one of the applied aspects of integrity and decency of official activity.

Establishing certain rules of ethical conduct and giving them a legal nature are aimed at implementing such tasks as: ensuring the professional and honest conduct of state servants, increasing the requirements that are set in view of the fact that these officials can: dispose of material and human resources; make decisions that can affect the rights and freedoms of individuals; to act in the conditions of realization of discretionary powers not formally regulated by the law, etc ${ }^{18}$. Therefore, compliance with the rules of ethical conduct is an important component of the professional activities of state servants.

Detailing of the rules of ethical conduct of state servants is carried out at the by-law level, namely the General Rules of Ethical Conduct ${ }^{19}$, which enshrine and regulate the implementation of public authorities and local governments of their rights and responsibilities to other legal entities, as well as inform the public about the necessary conduct they can expect from state servants. Moreover, the General Code of Ethical Conduct is a generalization of the ethical requirements for the conduct of state servants, which they are

\footnotetext{
17 Про запобігання корупції: Закон України від 14.10.2014 p. Дата оновлення 30.03.2020 p. URL: http://zakon2.rada.gov.ua/laws/show/1700-18 (дата звернення: 02.06.2020 p.); Про державну службу: Закон України від 10.12.2015 р. Дата оновлення 01.01.2020 p. URL: http://zakon2.rada.gov.ua/laws/show/889-19 (дата звернення: 01.06.2020р.).

${ }^{18}$ Науково-практичний коментар до Закону України «Про запобігання корупції» / Наук. ред. Хавронюк М.І. Київ: Ваіте, 2018. С. 268.

19 Загальні правилами етичної поведінки державних службовців та посадових осіб місцевого самоврядування: затв. наказом Національного агентства України з питань державної служби від 05.08.2016 р. № 158. URL: https://zakon.rada.gov.ua/laws/show/z1203-16 (дата звернення: 01.06.2020 р.).
} 
obliged to follow in the performance of official duties, and consists of six sections, which are marked by a kind of information content ${ }^{20}$.

Analysis of the General Rules of Ethical Conduct gives grounds to divide all ethical requirements depending on the content into the following three groups:

- organizational - contain a list of: a) the main responsibilities of state servants that affect the ethics and morality of their conduct (timely and strict implementation of decisions of public authorities, orders (directions), instructions of managers, improvement of state servants' skills, knowledge and acquirements in accordance with functions and tasks of the position, increasing their professional and cultural level, improving the organization of official activities, etc.); b) the peculiarities of the use of official position (the possibility of using own official position by a state servant exclusively for the performance of his official duties and instructions of managers and the prohibition to use it for political purposes, campaigning, actions and events organized by political parties or for illegal gain or satisfaction of personal interests); c) use of state resources (state servants are obliged to use state and communal property rationally and carefully, constantly increase the efficiency of its use, avoiding excessive and unnecessary expenses, as well as to prevent abuse and use of state property or funds in private interests; working time should be used only for the performance of official duties, the resources provided should be used in such a way as not to harm the environment or human health, etc.) ${ }^{21}$;

- information - disclose the essence of the rights and restrictions of a state servant on the use and exchange of information that became known in connection with the performance of official duties (it is prohibited to disclose personal data of individuals, confidential and other information with limited access; if there is information about the threat or facts of illegal dissemination of information with limited access, the obligation to immediately notify the direct head; compliance with the established protocol in relations with representatives of foreign authorities, international organizations, foreign institutions, etc.);

\footnotetext{
${ }^{20}$ Bilokur Ye.I., Danylenko Yu.S. On determining the state of legal regulation of the rules of ethical conduct of public servants. Правове життя сучасної України: матеріали Міжнар. наук.-практ. конф. (м. Одеса, 15 травня 2020 р.). у 2 т. Т. 2. / відп. ред. Г.О. Ульянова. Одеса: Видавничий дім «Гельветика», 2020. С. 20-23.

21 Загальні правилами етичної поведінки державних службовців та посадових осіб місцевого самоврядування: затв. наказом Національного агентства України з питань державної служби від 05.08.2016 р. № 158. URL: https://zakon.rada.gov.ua/laws/show/z1203-16 (дата звернення: 1.06 .2020 р.).
} 
- personal-provide for compliance by state servants with the following rules: in the performance of their duties to strictly adhere to generally accepted ethical standards of conduct; be polite and friendly; adhere to the rules of high culture of communication (for example, to prevent the use of obscene language, high intonation); to respect the rights, freedoms and legitimate interests of a human and citizen, associations of citizens and other legal entities; not to show arbitrariness or indifference to their lawful actions and demands. In addition, state servants must prevent conflicts in their dealings with citizens, managers, colleagues and subordinates ${ }^{22}$.

It seems that the General Rules of Ethical Conduct regulate the issues of ethics of state servants rather superficially, in particular without interpreting the content of certain regulations, which leads to the possibility for officials to use discretion in their official activities (for example, the requirement for the appearance of state servants and officials of local self-government contains an indication of the need to wear formal business style clothing and compliance with generally accepted requirements of decency. Instead, there is no separation of characteristics of such clothing. Moreover, the externalbehavioural side of interaction between people is more rules of etiquette than ethics). In addition, the main part of this normative legal act contains the norms provided by the Laws of Ukraine «On State Service» and «On Service in Local Self-Government Bodies ${ }^{23}$, and thus there is duplication of provisions enshrined in law (for example, section 2 is devoted to general responsibilities of a state servant and a local government official). It is seen that an important condition for enshrining in the normative level of rules of ethical conduct of state servants is to solve the problem of optimal ratio of the need to standardize official activities and individual freedom as an official and citizen, and hence the establishment of personal interaction in public administration.

It should be noted that until the issuance of the NASS Order on the settlement of ethics, these issues were regulated by the Resolution of the Cabinet of Ministers of Ukraine of 11.02.2016 On approval of the Rules of ethical conduct of state servants, which were in force until $22.03 .2017^{24}$, i.e.

22 Загальні правилами етичної поведінки державних службовців та посадових осіб місцевого самоврядування: затв. наказом Національного агентства України з питань державної служби від 05.08.2016 р. № 158. URL: https://zakon.rada.gov.ua/laws/show/z1203-16 (дата звернення: 1.06 .2020 р.).

${ }^{23}$ Про службу в органах місцевого самоврядування: Закон України від 07.06.2001 p. № 2493-III. Дата оновлення 20.03.2020 p. URL: https://zakon.rada.gov.ua/laws/show/249314\#Техt (дата звернення: 02.06.2020 р.).

${ }^{24}$ Про затвердження Правил етичної поведінки державних службовців: Постанова Кабінету Міністрів України від 11.02.2016 р. № 65. URL: https://zakon.rada.gov.ua/laws/show/652016-\%D0\%BF\#Техt (втрата чинності: 22.03.2017 р.). 
for more than seven months (August 5, 2016 - March 23, 2017) in Ukraine there were two regulations that regulated ethical rules for state servants. However, despite the higher legal force of the resolutions of the Cabinet of Ministers, law enforcement priority in this period was given to ethical rules adopted by the central executive body, which ensures the formation and implementation of public policy in the state service, because the Law of Ukraine «On Prevention of Corruption» assigned the appropriate lawmaking function on this body.

The opinion of O.P. Khamkhodera seems to be appropriate. The scientist draws attention that despite the fact that these rules have expired, they enshrined a meaningfully consistent and harmonious system of ethical principles, the content of most of which is reflected in the current General Rules of Ethical Conduct for State Servants and Local Government Officials; however, the latter are formulated as a set of requirements and rules, without naming the fundamental ethical principles and without systematizing the existing ethical and legal requirements for the content of such principles. The list of rules of ethical conduct provided by the Rules of ethical conduct for state servants does not take into account two aspects: a) the principle of transparency and accountability, which is more general than ethical; b) the principle of loyalty, which is the only one that has not been reproduced in the current General Rules ${ }^{25}$.

Regarding the principle of loyalty, it should be noted that it contained a requirement to refrain from any manifestations of public criticism of the activities of state bodies, their officials, which was perceived as a deviation from the provisions of Art. 34 of the Constitution of Ukraine (the right to freedom of thought and speech, to free expression of their views and beliefs) ${ }^{26}$ and Art. 10 of the Convention for the Protection of Human Rights and Fundamental Freedoms (freedom of expression) ${ }^{27}$. At the same time, this principle is in fact enshrined in the Model Code of Conduct for State Servants of the Council of Europe in 2000 (the need to act politically neutral and not try to create obstacles to legitimate policies, decisions and actions of public authorities; commitment to serve the legitimate state, regional and

\footnotetext{
${ }_{25}$ Адміністративне право України. Повний курс: підручник. Херсон: ОЛДІ-ПЛЮС, 2019. C. 333 .

${ }^{26}$ Конституція України. Із змінами, внесеними Законом України від 08.12.2004 p. № 2222-IV. Дата оновлення 01.01.2020 p. URL: http://zakon2.rada.gov.ua /laws/show/254\%D0\%BA/96$\% \mathrm{D} 0 \% \mathrm{~B} 2 \% \mathrm{D} 1 \% 80$ (дата звернення: 01.06.2020р.).

${ }^{27}$ Конвенції про захист прав людини i основоположних свобод. URL: https://zakon.rada.gov.ua/laws/show/995_004\#Text (дата звернення: 01.06.2020р.).
} 
local authorities ${ }^{28}$. Moreover, loyalty to the state system, the activities of public authorities, in particular the Cabinet of Ministers and official state policy should not imply loyalty to the ruling political party. And giving state servants the organizational opportunity to express their comments on the activities of individual government entities to senior management is a real opportunity to increase the efficiency and effectiveness of their operation (as an example, in the form of proposals to improve existing legislation).

The rules of ethical conduct in the activities of state servants of the specialized state service (police, prosecutors) are regulated by separate regulations, in particular: the Code of Professional Ethics and Conduct of Prosecutors $^{29}$, the Code of Ethical Conduct of Police ${ }^{30}$, etc.

Other laws and by-laws enshrine certain aspects of professional ethics, the actualization of which is due to certain social needs. These include the annual messages of the President of Ukraine to the Verkhovna Rada of Ukraine, decrees of the President of Ukraine aimed at improving public administration and the moral sphere of public life, as well as resolutions and orders of the Cabinet of Ministers of Ukraine, instructional materials of the National State Service Agency, National Agency for the Prevention of Corruption, etc.

Thus, the normative level establishes a system of rules of ethical conduct that perform cognitive, regulatory and value-oriented functions, formalize and unify the requirements for the conduct of state servants by: fixing standards of conduct of public officials; determination of the moral and ethical climate that should be formed in a particular area of performance of official or representative powers; informing the public about the standards of interaction of public representatives with state servants. The purpose of translating the ethical norms of conduct of a state servant into the legal plane is: 1) to stimulate high standards of conduct of a state servant; 2) strengthening public confidence in state servants; 3 ) the formation of a new image of state power; 4) development of a moral basis for avoiding corruption in the state service.

\footnotetext{
${ }_{28}$ Модельний кодекс поведінки державних службовців: Рекомендація Комітету Міністрів № R (2000) 10 від 11.05.2000 p. URL: http://www.dridu.dp.ua/cpk/Lib/7_Zapobigannya\%20 ta\%20protydiya\%20proyavam\%20korup/Legislation/Legislature/Rekomend_poved_DS.pdf (дата звернення: 01.06.2020 р.).

${ }^{29}$ Кодекс професійної етики та поведінки прокурорів: Закон України від 24.04.2017 р. Дата оновлення 01.01.2020 p. URL: https://zakon.rada.gov.ua/laws/show/n0001900-17 (дата звернення: 1.06 .2020 р.).

${ }^{30}$ Про затвердження Правил етичної поведінки поліцейських: наказ МВС 09.11.2016 p. № 1179. Дата оновлення 01.01.2020 p. URL: https://zakon.rada.gov.ua/laws/show/z1576-16 (дата звернення: 1.06.2020р.).
} 


\section{CONCLUSIONS}

It is determined that the ethics of state servant conduct is a legally defined system of ethical norms and principles, procedures, rules and relationships not only in state service relations, but also outside them, based on the values of state service and awareness of state servants of their professional purpose.

The following components of the ethics of conduct of state servants are singled out, as: a) theoretical - a set of acquired during the life ethical knowledge and moral values; b) practical - attitudes to proper conduct and application of acquired knowledge in professional activities.

The expediency of dividing the rules of ethical conduct of state servants into two groups depending on the limits of their distribution is substantiated: 1) rules that apply to the official activities of state servants; 2) rules that apply to the conduct outside of official activities and do regulate privacy.

It is established that the General Rules of Ethical Conduct superficially regulate the issues of ethics of conduct of state servants, in particular without interpretation of the content of certain instructions, which leads to the possibility and / or necessity of officials using discretion in their official activities. It was clarified that the purpose of translating the ethical norms governing the conduct of state servants into the legal plane is: a) to encourage high standards of conduct of state servants; b) strengthening public confidence in state servants; c) the formation of a new image of state power; d) development of a moral basis for avoiding corruption in the state service.

\section{SUMMARY}

The article is devoted to the study of the ethics of conduct of state servants as a qualitative component of the content of public administration. The concept of «ethics of conduct of state servants» is defined and the characteristic features of its content are clarified. Particular attention is paid to the issue of legal regulation of the rules of ethical conduct of state servants.

It is determined that the establishment of the rules of ethical conduct of state servants is intended to: help to prevent the commission of corruption or corruption-related offenses by state servants; to ensure an increase of the level of official discipline during service in public authorities; increase the personal responsibility of state servants for the performance of their duties.

There are three groups of ethical requirements for state servants depending on the content, as: 1) organizational; 2) information; 3) personal. It was found that the General Rules of Ethical Conduct regulate the issues of 
ethics of state servants rather superficially, in particular without interpreting the content of certain regulations, which leads to the possibility for officials to use discretion in their official activities.

It is determined that for violation of the rules of ethical conduct by state servants such types of legal consequences are applied to them as: a) bringing to legal responsibility (criminal, administrative, disciplinary); b) the onset of organizational and procedural consequences.

\section{REFERENCES}

1. Адміністративне право України. Повний курс : підручник. Херсон : ОЛДІ-ПЛЮС, 2019. с. 333. 520 с.

2. Василевська Т.Е. Особистісні виміри професійної етики державного службовця: дис. ... доктор наук з держ. управління. Киїі, 2009. 427 с.

3. Даниленко Ю.С., Назарчук А.В. Щодо питання змістовної характеристики правил етичної поведінки державних службовців. Верховенство права у процесі державотворення та захисту прав людини в Україні: матеріали міжнародної науково-практичної конференції (м. Одеса, Україна, 7-8 лютого 2020 р.). Одеса : ГО «Причорноморська фундація права», 2020. С. 112-114.

4. Даниленко Ю.С. Правила етичної поведінки державних службовців: поняття та сутність. Вісник Чернівецького факультету Національного університету «Одеська юридична академія». Чернівці, 2019. № 2. C. 54-64.

5. Загальні правилами етичної поведінки державних службовців та посадових осіб місцевого самоврядування: затв. наказом Національного агентства України 3 питань державної служби від 05.08.2016 p. № 158. URL : https://zakon.rada.gov.ua/laws/show/z1203-16 (дата звернення: 01.06.2020 p.).

6. Кодекс про адміністративні правопорушення України від 07.12.1984 p. Дата оновлення: 19.01.2020 p. URL : https://zakon.rada.gov.ua/ laws/show/80731-10 (дата звернення: 01.06.2020 p.).

7. Кодекспрофесійноїетикитаповедінкипрокурорів:Закон Українивід 24.04.2017 p. Дата оновлення 01.01.2020 p. URL : https://zakon.rada.gov.ua/ laws/show/n0001900-17 (дата звернення: 01.06.2020 p.).

8. Конвенція Організації Об'єднаних Націй проти корупції від 31.10.2003 p. URL : https://zakon.rada.gov.ua/laws/show/995_c16\#Text (дата звернення: 01.06.2020р.).

9. Конвенції про захист прав людини і основоположних свобод. URL : Режим доступу: https://zakon.rada.gov.ua/laws/show/995_004\#Text (дата звернення: 01.06.2020 p.). 
10. Конституція України. Із змінами, внесеними Законом України від 08.12.2004 p. № 2222-IV. Дата оновлення 01.01.2020 p. URL : http://zakon2.rada.gov.ua/laws/show/254\%D0\%BA/96-\%D0\%B2\%D1\%80 (дата звернення: 01.06.2020р.).

11. Кримінальний кодекс України : Закон України від 5.04.2001 p. № 2341-III. Дата оновлення: 05.06.2020 p. URL : https://zakon.rada.gov.ua/ laws/show/2341-14\#Text (дата звернення: 01.06.2020р.).

12. Модельний кодекс поведінки державних службовців: Рекомендація Комітету Міністрів № R (2000) 10 від 11.05 .2000 p. URL : http://www.dridu.dp.ua/ cpk/Lib/7_Zapobigannya\%20ta\%20protydiya\%20proyavam\%20korup/ Legislation/Legislature/Rekomend_poved_DS.pdf(дата звернення: 01.06.2020 p.).

13. Науково-практичний коментар до Закону України «Про запобігання корупції» / Наук. ред. Хавронюк М.І. Київ : Ваіте, 2018. 472 с.

14. Про державну службу: Закон України від 10.12 .2015 р. Дата оновлення 01.01.2020 p. URL : http://zakon2.rada.gov.ua/laws/show/88919 (дата звернення: 01.06.2020 р.)

15. Про запобігання корупції : Закон України від 14.10.2014 р. Дата оновлення 30.03.2020 p. URL : http://zakon2.rada.gov.ua/laws/show/170018 (дата звернення: 02.06.2020р.).

16. Про затвердження Правил етичної поведінки державних службовців: Постанова Кабінету Міністрів України від 11.02.2016 р. № 65. URL : https://zakon.rada.gov.ua/laws/show/65-2016-\%D0\%BF\#Text (втрата чинності: 22.03.2017 р.).

17. Про затвердження Правил етичної поведінки поліцейських: наказ MBC 09.11.2016 p. № 1179. Дата оновлення 01.01.2020 p. URL: https:// zakon.rada.gov.ua/laws/show/z1576-16 (дата звернення: 01.06.2020 p.).

18. Про службу в органах місцевого самоврядування : Закон України від 07.06.2001 р. № 2493-III. Дата оновлення 20.03.2020 p. URL : https:// zakon.rada.gov.ua/laws/show/2493-14\#Text (дата звернення: 02.06.2020р.).

19. Публічна служба. Зарубіжний досвід та пропозиції для України / за заг. ред. Тимощука В. П., Школика А. М. Київ: Конус Ю, 2007. 735 с.

20. Рудакевич М.I. Професійна етика державних службовців: теорія і практика формування в умовах демократизації державного управління: монографія. Тернопіль: Видво АСТОН, 2007. 400 с.

21. Bilokur Ye. I., Danylenko Yu. S. On determining the state of legal regulation of the rules of ethical conduct of public servants. Правове життя сучасної України: матеріали Міжнар. наук.-практ. конф. (м. Одеса, 15 травня 2020 р.). у 2 т. Т. 2. / відп. ред. Г.О. Ульянова. Одеса : Видавничий дім «Гельветика», 2020. С. 20-23.

22. Ethics in the public service: Current issues and practice. Paris: OECD, 1996. 66 p. (Series “Public Management Occasional Papers”, no. 14). 
Information about author:

Bilokur Ye. I.,

$\mathrm{PhD}$ in Law,

Associate Professor at the Department of Administrative and Financial Law National University "Odesa Law Academy" 23, Fontanska doroha str., Odesa, 65009, Ukraine

Danylenko Yu. S., $\mathrm{PhD}$ in Law, Associate Professor at the Department of Administrative and Financial Law National University "Odesa Law Academy" 23, Fontanska doroha str., Odesa, 65009, Ukraine 